\title{
PERSEPSI KEPALA SEKOLAH TERHADAP KINERJA GURU PJOK SEKOLAH MENENGAH ATAS NEGERI DI KOTA BNGKULU
}

\author{
Erik Estrada \\ Mahasiswa S-1 Pendidikan Jasmani, email: erikestrada3008@gmail.com \\ Universitas Bengkulu \\ Dian Pujianto \\ Universitas Bengkulu \\ Arwin \\ Universitas Bengkulu
}

\begin{abstract}
Abstrak
Penelitian ini bertujuan untuk mengetahui Persepsi Kepala Sekolah terhadap Kinerja Guru PJOK Sekolah Menengah Atas Negeri di Kota Bengkulu. Jenis penelitian ini adalah deskriptif kualitatif. Subyek pada penelitian ini adalah Kepala Sekolah Sekolah Menengah Atas Negeri di Kota Bengkulu dengan jumlah responden sebanyak 11 orang. Teknik pengumpulan data yang digunakan adalah dengan angket (kuisioner), dan dokumentasi. Intrumen yang digunakan adalah angket tertutup. Teknik analisis data yang digunakan adalah persentase. Hasil penelitian ini diambil dari angket Kepala sekolah yang berjumlah 11 orang, maka di perolah hasil angket dengan kategori : 1) kompetensi pedagogik sebesar $86,18 \%$ dalam kriteria sangat baik, 2) kompetensi kepribadian sebesar $87,45 \%$ dalam kriteria sangat baik, 3) kompetensi profesional sebesar $85,64 \%$ dalam kriteria sangat baik, dan 4) kompetensi sosial sebesar $88,36 \%$ dalam kriteria sangat baik. Sehingga dapat disimpulkan bahwa Persepsi Kepala Sekolah Terhadap Kinerja Guru PJOK Se-SMA Negeri di Kota Bengkulu Sangat Baik.
\end{abstract}

Kata Kunci : Persepsi, Kepala Sekolah, Kinerja, Guru PJOK.

\begin{abstract}
This research is aimed to know Perception of Headmaster towards Sports Teacher's Work of Senior High School in Bengkulu City. Kind of this research is qualitative descriptive. Subject of this research is whole headmaster of Senior High School in Bengkulu City with 11 respondents. Technique of collecting the data which is used is questionnaire, and documentation. Instrument which is used is closed questionnaire. Technique of analysing the data which is used is percentation. Result of the research was taken from questionnaire of 11 headmasters, so it got the result of questionnaire with category: 1) Pedagogic Competency was 86, $18 \%$ in very good criteria, 2) Personality Competency was 87,45\% in very good criteria, 3) Professional Competency was $85,64 \%$ in very good criteria, and 4) Social Competency was $88,36 \%$ in very good criteria. Therefore, it can be concluded that Perception of Headmaster towards Sport Teacher's Work at Senior High School in Bengkulu City is Very Good.
\end{abstract}

Keywords: Perception, Headmaster, Work, Sports Teacher 


\section{PENDAHULUAN}

Pendidikan

merupakan kebutuhan setiap orang dalam kehidupannya, pertumbuhan dan perkembangan seseorang yang bersifat kualitatif juga merupakan hasil dari proses pendidikan, baik disadari maupun tidak disadari. Pendidikan bermaksud mengembangkan segala potensi yang dimiliki individu yang secara alami sudah dimiliki. Potensi yang ada pada individu tersebut apabila tidak dikembangkan menjadi surnber daya yang terpendam tanpa dapat kita lihat dan rasakan hasilnya, untuk itu individu perlu diberi berbagai kemampuan dalam pengembangan berbagai hal antara lain: konsep, prinsip, kreativitas, tanggung jawab, dan ketrampilan. Individu juga makhluk yang ingin berinteraksi dengan lingkungannya. Objek sosial ini berpengaruh terhadap perkembangan individu, Melalui pendidikan dapat dikembangkan suatu keadaan yang seimbang serta perkembangan aspek individual dan aspek sosial.

\section{Menurut Undang-Undang}

Republik Indonesia No. 14 Tahun 2005 tentang Guru dan Dosen: "Guru adalah pendidik profesional dengan tugas utama mendidik, mengajar, membimbing, mengarahkan, melatih, menilai dan mengevaluasi peserta didik pada pendidikan anak usia dini jalur pendidikan formal, pendidkan dasar, dan pendidikan menengah". Dalam Undang-Undang No. 14 Tahun 2005 dijelaskan bahwa: "Guru mempunyai kedudukan sebagai tenaga profesional pada jenjang pendidikan usia dini,pendidikan dasar, pendidikan menengah, pada jalur pendidikan formal yang diangkat sesuai dengan peraturan perundang-undangan.

Dalam dunia pendidikan, kinerja seorang guru sangat berpengaruh pada tingkat keberhasilan siswa. Guru berperan penting dalam membantu pertumbuhan dan perkembangan para siswa. Peran dan kinerja guru dalam pengelolaan pembelajaran menjadi hal yang penting karena berkaitan langsung dengan aktivitas belajar siswa. Upaya guru untuk menguasai bahan ajar, merencanakan, dan melaksanakan kegiatan pembelajaran dengan optimal dapat terwujud jika dalam diri guru ada dorongan dan tekad yang kuat untuk komitmen menjalankan tugasnya dengan baik.

Berdasarkan kajian pada latar belakang masalah di atas, maka dapat di rumuskan beberapa permasalahan dalam penelitian ini antara lain:

1. Masih ditemukan kurangnya kedisiplinan guru pendidikan jasmani dalam melaksanakan tugasnya.

2. Masih ditemukan banyaknya penyampaian materi yang monoton dan kurang bervariatif.

3. Masih banyaknya pertanyaan tentang bagaimana kinerja guru PJOK dalam melaksanakan tugas mengajar.

4. Belum tercapai tujuan dari pembelajaran PJOK.

5. Sarana dan prasarana belum mendukung.

6. Jumlah guru yang memiliki sertifikasi sangat terbatas.

7. Kapasitas guru dalam menyampaikan materi belum maksimal. 
Fenomena yang terjadi berdasarkan pengamatan, guru-guru khususnya guru Pendidikan Jasmani Olahraga dan Kesehatan (PJOK) Sekolah Menengah Atas Negeri di Kota Bngkulu menunjukkan bahwa guru dalam melaksanakan tugasnya hanya berdasarkan materi pokok tanpa memperhatikan materi ajar bagi jenjang pendidikan dasar, dan juga tanpa berpedoman pada Rencana Pelaksanaan Pembelajaran yang telah disahkan oleh kepala sekolah. Masyarakat umum mempunyai pendapat yang perlu diperhatikan oleh guru penjas, beberapa masalah yang mendapat sorotan tentang kinerja guru penjas yang tampak dari luar antara lain: kurangnya kedisiplinan guru dalam mengajar, apakah guru penjas memakai pakaian olahraga pada saat mengajar, apakah guru memperhatikan keselamatan siswa dan mengevaluasi setelah pelajaran disekolah.

Menurut Supardi (2013 : 45) menjelaskan bahwa kinerja merupakan suatu kegiatan yang dilakukan untuk melaksanakan, menyelesaikan tugas, dan tanggung jawab sesuai dengan harapan dan tujuan yang telah ditetapkan. Pendapat lain di sampaikan oleh Whitmore dalam H.B Uno dan Nina Lamatenggo (2014 : 60) kinerja adalah sesuatu perbuatan, suatu prestasi, atau apa yang diperlihatkan seseorang melalui keterampilan yang nyata.implementasi adalah perluasan aktivitas yang saling menyesuaikan proses interaksi antara tujuan dan tindakan untuk mencapainya serta memerlukan jaringan pelaksana, birokrasi yang efektif. Serta membutuhkan pelaksanaan dan penerapan yang konsisten dalam hal yang sudah dirancang dan diterapkan di lapangan. Sehingga tercapai hal yang diinginkan. (Setiawan, 2004:39).

Untuk mengetahui kinerja guru di sekolah, bisa diketahui melalui persepsi dari orang lain yang ada di lingkungan sekolah. Sekolah merupakan salah satu organisasi pendidikan yang dapat dikatakan sebagai wadah untuk mencapai tujuan pembangunan nasional. Keberhasilan tujuan pembangunan nasional di sekolah tergantung pada sumber daya manusia yang berada di sekolah tersebut yaitu kepala sekolah, guru, siswa, pegawai tata usaha dan tenaga kependidikan lainnya. Selain itu harus didukung pula oleh sarana dan prasarana yang memadai, untuk membentuk manusia yang sesuai dengan tujuan pembangunan nasional yang hakekatnya bertujuan meningkatkan kualitas manusia dan seluruh masyarakat Indonesia yang maju, modern berdasarkan pancasila, maka dibutuhkan tenaga pendidik yang berkualitas.

Menurut Bimo Walgito (2004 : 87-88) persepsi merupakan "suatu proses yang didahului oleh proses pengindraan, yaitu merupakan proses diterimanya stimulus oleh individu melalui alat indera atau juga disebut proses sensoris". Persepsi merupakan proses yang integrated dalam diri individu terhadap stimulus yang di terimanya. (Moskowitz dan Orgel dalam Bimo Walgito, 2004 : 88). Pendapat lain di sampaikan oleh (supardi, 2011: 167) bahwa persepsi mengacu pada mekanisme yang menjadi alat kita menyadari dan memproses informasi tentang proses stimulus ataupun dunia eksternal, baik itu menyangkut tentang kualitas kognitif maupun efektif. Sejalan dengan 
teori tersebut (Desmita, 2006 : 108) juga merumuskan pengertian persepsi pada dasarnya menyangkut hubungan manusia dengan lingkunagnnya, bagaimana ia mengerti dan menginterpretasikan stimulus yang ada disekitarnya untuk kemudian diproses melalui alat indra sehingga menimbulkan makna mengenai objek yang di persepsi. Persepsi merupakan proses menerima informasi membuat pengertian tentang dunia di sekitar kita.

Kepala Sekolah pada hakikatnya
adalah pejabat formal, sebab
pengangkatannya melalui suatu proses
dan prosedur yang didasarkan atau
peraturan yang berlaku. Secara sistem
jabatan atau pemimpin formal dapat
diuraikan melalui berbagai pendekatan,
pengangkatan, pembinaan dan
tanggung jawab (H. Mintzberg dalam
Wahjosumidjo, 2003:85).
Wahjosumidjo, $2003: 85$ ).

Guru adalah orang yang
pekerjaannya atau mata pencahariannya atau profesi mengajar, sehingga guru pendidikan jasmani dapat diartikan sebagai orang yang pekerjaannya atau profesinya mengajar mata pelajaran pendidikan jasmani. Tugas guru yang paling utama adalah bagaimana mengkondisikan lingkungan belajar yang menyenangkan agar dapat membangkitkan rasa ingin tahu semua peserta didik sehingga tumbuh minat dan nafsunya untuk belajar (E. Mulyasa (2006 : 35).

Pendidikan jasmani merupakan bagian mutlak dari seluruh lingkup usaha pendidikan. Pendidikan jasmani bukanlah lawan dari pendidikan rohani tetapi pendidikan jasmani adalah usaha pendidikan yang menggunakan jasmani sebagai titik pangkal usahanya (Subagiyo, 2004 : 116).
Peneliti melakukan observasi ke sekolah-sekolah yang ada di sekolah menengah atas negeri Kota Bengkulu. Untuk melihat bagaimana "Persepsi Kepala Sekolah terhadap Kinerja Guru PJOK Sekolah Menengah Atas Negeri di Kota Bengkulu".

\section{METODE}

Jenis penelitian ini adalah penelitian kualitatif, menurut Bogdan \& Taylor(dalam Gunawan, 2013:82) penelitian kualitatif adalah prosedur penelitian yang menghasilkan data deskriptif berupa kata-kata tertulis atau lisan dari orang-orang dan berperilaku yang dapat diamati yang diarahkan pada latar dan individu secara holistik (utuh). Gunawan (2013:112) mengatakan salah satu jenis penelitian kualitatif adalah penelitian dengan menggunakan metode atau pendekatan bersifat studi kasus (case study). Penelitian studi kasus memusatkan diri secara intensif, tentang latar belakang masalah keadaan dan posisi suatu peristiwa yang yang sedang berlangsung saat ini, serta interaksi lingkungan unit sosial tertentu yang bersifat apa adanya (given).Menurut Sugiono (2013:376), Mengatakan teknik pengumpulan data dapat dilakukan dengan kuesioner (angket) dan dokumentasi.

Menurut sugioyono (2011:216) subjek penelitian merupakan nara sumber, parsipan, informan yang dapat memberikan informasi-informasi yang dibutuhkan dalam penelitan karena tujuan penelitian kualitatif adalah untuk menghasilkan teori. Pengambilan subjek dalam penlitian ini menggunakan tehnik purposive, yaitu dengan memilih orang-orang yang dianggap tahu tentang focus masalah 
seperti pihak yang terkait dengan pengambilan keputusan seperti semua Kepala Sekolah Sekolah Menengah Atas Negeri di Kota Bengkulu dengan jumlah 11 orang.

Subyek dalam penelitian ini adalah seluruh Kepala Sekolah Sekolah Menengah Atas Negeri di Kota Bengkulu. Dengan demikian, penelitian tentang Persepsi Kepala Sekolah terhadap Kinerja Guru PJOK Sekolah Menengah Atas Negeri di Kota Bengkulu merupakan penelitian kualitatif. Penelitian ini menggunakan teknik pengumpulan data berupa kata kata tertulis atau lisan, gambar, foto atau tindakan yang diperoleh dari sumber data, yaitu: orang, tulisan dan tempat. Metode pengumpulan data yang benar akan menghasilkan data yang memiliki kredibilitas tinggi. Ada beberapa metode dalam pengumpulan data kualitatif menurut Suharsimi Arikunto (2010:193).

\section{a. Pengamatan / Observasi}

Observasi merupakan suatu kegiatan mendapatkan informasi yang diperlukan untuk menyajikan gambaran ril suatu preristiwa atau kejadian untuk menjawab pertanyaan penelitian, untuk membantu mengerti prilaku manusia dan untuk evaluasi yaitu melakukan pengukuran terhadap aspek tertentu melakukan umpan balik terhadap pengukuran tersebut. Hasil observasi berupa aktifitas, kejadian, pristiwa, objek, kondisi atau suasana tertentu. Dalam hal ini untuk mengetahui dari Persepsi Kepala Sekolah Terhadap Kinerja Guru PJOK Se-SMA Negeri di Kota Bengkulu.

\section{b. Angket atau kuesioner}

Angket atau kuesioner merupakan tehnik pengumpulan data yang dilakukan dengan cara memberi sepererangkat pertanyaan atau pernyataan tertulis kepada responden untuk dijawab. Dalam hal ini untuk mengetahui persepsi atau pendapat tentang Persepsi Kepala Sekolah Terhadap Kinerja Guru PJOK Sekolah Menengah Atas Negeri di Kota Bengkulu.

\section{c. Dokumentasi}

Dokumentasi merupakan metode pengumpulan data kualitatif sejumlah besar fakta dan data tersimpan dalam bahan yang berbentuk dokumentasi. Sebagian data berbentuk surat, catatan harian, arsip foto, hasil rapat, cendramata, jurnal kegiatan dan sebagainya. Dokumentasi ini untuk memperkuat data yang diperoleh dengan observasi, kuesioner/angket.

\section{HASIL DAN PEMBAHASAN}

Hasil

Dari angket yang disebar ke sekolah sebanyak 11 orang dengan 40 pertanyaan maka diperoleh hasil dengan uji analisis persentase. Ringkasan dari hasil analisis data tersebut dapat dilihat pada tabel $4 \mathrm{di}$ bawah ini.

Dari hasil analisis data penelitian yang ada di atas maka dapat dilihat bahwa Persepsi Kepala Sekolah Terhadap Kinerja Guru PJOK Sekolah Menengah Atas Negeri di Kota Bengkulu mempunyai persepsi yang baik tentang kompetensi pedagogik dengan skor 460 (86,18\%), Persepsi Kepala Sekolah yang sangat baik tentang kompetensi kepribadian 
dengan skor $481(87,45 \%)$, persepsi yang baik tentang kompetensi profesional dengan skor 471 (85,64\%), dan persepsi yang sangat baik tentang kompetensi sosial dengan skor 486 (88,36\%). Sehingga dapat disimpulkan bahwa Persepsi Kepala Sekolah Terhadap Kinerja Guru PJOK Sekolah Menengah Atas Negeri di Kota Bengkulu memiliki kriteria yang baik dengan rata-rata skor $474,5(86,27 \%)$. Hasil analisis data penelitian juga dapat dilihat dalam bentuk grafik batang seperti gambar di bawah.

Berdasarkan dari indikator yang memahami peserta didik lebih mendalam memiliki presentase $(83,64$ $\%)$, merancang pembelajaran termasuk memahami landasan pendidikan untuk kepentingan pembelajaran memiliki presentase (88,49\%), melaksanakan pembelajaran memiliki presentase $(86,06)$, merancang dan melaksanakan evaluasi pembelajaran memilki presentase $(84,55 \%)$, mengembangkan potensi peserta didik memiliki presentase (85,45\%). Jadi dapat disimpulkan bahwa dari kelima ietem di atas, indikator merancang pembelajaran termasuk memahami landasan pendidikan untuk kepentingan pembelajaran merupakan skor tertinggi dengan presentase $88,49 \%$. Sedangkan untuk skor terendah adalah indikator memahami peserta didik lebih mendalam dengan presentase $83,64 \%$.

\section{1) Kompetensi Kepribadian}

Berdasarkan data yang diperoleh dari 11 responden dari Kepala Sekolah Se-SMA Negeri di Kota Bengkulu, untuk kompetensi pedagogik ini penulis membagikan angket kepada responden sebanyak 10 item dan diperoleh hasil sebagai berikut.

Berdasarkan data yang telah di isi responden dari 10 item pernyataan yang terdiri dari indikator bertindak sesuai dengan norma agama, hukum, sosial dan kebudayaan nasional Indonesia memiliki kriteria yang sangat baik dengan mean 4,64 (92,73\%), menampilkan diri sebagai pribadi yang jujur, berakhlak mulia, dan teladan bagi peserta didik dan masyarakat memiliki kriteria sangat baik dengan mean 4,45 (89,09\%), menampilkan diri sebagai pribadi yang mantap, stabil, dewasa, arif dan berwibawa memiliki kriteria yang sangat baik dengan mean 4,23. (84,55\%), etos kerja, tanggung jawab yang tinggi, rasa bangga menjadi guru dan rasa percaya dirimemiliki kriteria sangat baik dengan mean 4,36 $(87,27 \%)$, menjunjung tinggi kode etik profesi guru memiliki kriteria sangat baik dengan mean 4,27 (85,46\%). Sehingga dapat disimpulkan bahwa Persepsi Kepala Sekolah Terhadap Kinerja Guru PJOK memiliki kriteria yang sangat baik dengan rata-rata mean 4,39 (87,82\%). Hasil analisis data penelitian juga dapat dilihat dalam bentuk histogram seperti gambar di bawah.

Berdasarkan dari indikator yang bertindak sesuai dengan norma agama, hukum, sosial dan kebudayaan nasional indonesia memiliki presentasi $(92,73 \%)$, menampilkan diri sebagai pribadi yang jujur, berakhlak mulia, dan teladan bagi peserta didik dan masyarakat memiliki presentase $(89,09)$, menampilkan diri seabgai pribadi yang mantap, stabil, dewasa, arif dan beribawa memiliki presentase (84,55\%), etos kerja, tanggung jawab yang tingi, ras bangga 
menjadi guru dan rasa percaya diri memiliki presentse $(87,27 \%)$, menjunjung tinggi kodek etik profesi guru memiliki presentase $(85,46 \%)$. Jadi dapat disimpulkan bahwa dari kelima ietem di atas, indikator bertindak sesuai dengan norma agama, hukum, sosial dan kebudayaan nasional indonesia merupakan skor tertinggi dengan presentase (92,73\%). Sedangkan untuk skor terendah adalah indikator menampilkan diri sebagai pribadi yang mantap, stabil, dewasa, arif dan beribawa dengan presentase $(84,55 \%)$.

\section{2) Kompetensi Profesional}

Berdasarkan data yang diperoleh dari 11 responden dari Kepala Sekolah Sekolah Menengah Ata Negeri di Kota Bengkulu, untuk kompetensi pedagogik ini penulis membagikan angket kepada responden sebanyak 10 item dan diperoleh hasil sebagai berikut.

Berdasarkan data yang telah di isi responden dari 10 item pernyataan yang terdiri dari indikator penguasaan materi struktur konsep dan pola pikir keilmuan yang mendukung mata pelajaran yang diampu memiliki kriteria yang baik dengan mean 4,23 (84,55\%), menguasai standar kompetensi dan kompetensi dasar mata pelajaran yang diampu memiliki kriteria baik dengan mean 4,27 (85,45\%), mengembangkan keprofesian melalui tindakan reflektif memiliki kriteria yang baik dengan mean 4,27 (85,46\%), memanfaatkan teknologi informasi dan komunikasi untuk mengembangkan diri memiliki kriteria baik dengan mean 4,33 (86,67\%), Sehingga dapat disimpulkan bahwa Persepsi Kepala Sekolah Terhadap Kinerja Guru PJOK Sekolah Menengah Atas Negeri di Kota
Bengkulu memiliki kriteria yang baik dengan rata-rata mean $4,28(85,53 \%)$. Hasil analisis data penelitian juga dapat dilihat dalam bentuk histogram seperti gambar di bawah.

Berdasarkan dari indikator yang pengusaan materi struktur konsep dan pola pikir keilmuan yang mendukung mata pelajaran yang mampu memiki presentase $(84,55 \%)$, menguasai standar kompetensi dan kompetensi dasar mata pelajaran yang diampuh memiliki presentase (85,45\%), mengembangkan keprofesian melalui tindakan reflektip memiliki presentase $(85,46 \%)$, memamfaatkan teknologi informasi dan komunikasi untuk mengembangkan diri memiliki prsentase (86,67\%). Jadi dapat disimpulkan bahwa dari ke empat item di atas, indikator memamfaatkan teknologi dan komunikasi untuk mengembangkan diri merupakan skor tertinggi dengan presentase $(86,67 \%)$. Sedangkan untuk skor terendah adalah penguasaan materi struktur konsep dan pola pikir keilmuan yang mendukung mata pelajaran yang diampuh dengan presentase $(84,55 \%)$.

\section{3) Kompetensi sosial}

Berdasarkan data yang diperoleh dari 11 responden dari Kepala Sekolah Se-SMA Negeri di Kota Bengkulu, untuk kompetensi pedagogik ini penulis membagikan angket kepada responden sebanyak 10 item dan diperoleh hasil sebagai berikut.

Berdasarkan data yang telah di isi responden dari 10 item pernyataan yang terdiri dari indikator bersikap inklusif, bertindak obyektif, serta tidak diskriminatif. Memiliki kriteria yang sangat baik dengan mean 4,41 
$(88,18 \%)$, berkomunikasi secara efektif, empatik, dan santun dengan sesama pendidik, tenaga kependidikan, orang tua, dan masyarakat memiliki kriteria sangat baik dengan mean 4,49 $(89,70 \%)$, beradaptasi ditempat bertugas di seluruh wilayah Republik Indonesia yang memiliki keragaman sosial budaya memiliki kriteria yang sangat baik dengan mean 4,37 $(87,27 \%)$, berkomunikasi dengan komunitas profesi sendiri dan profesi lain secara lisan dan tulisan atau bentuk lain. Memiliki kriteria sangat baik dengan mean 4,41 (88,18\%). Sehingga dapat disimpulkan bahwa Persepsi Kepala Sekolah Terhadap Kinerja Guru PJOK Sekolah Menengah Atas Negeri di Kota Bengkulu memiliki kriteria yang sangat baik dengan rata-rata mean 4,42 (88,33\%). Hasil analisis data penelitian juga dapat dilihat dalam bentuk histogram seperti gambar di bawah.

Berdasarkan dari indikator yang bersikap inklusif, bertindak objektif, serta tidak diskriminatif memiki presentase $(88,18 \%)$, berkomunikasi secara efektif, empatik, dan santun sesama pendidik, tenaga kependidikan, orang dan masyarakat memiliki presentase $(89,70 \%)$, beradaptasi di tempat bertugas di seluruh wilayah republik indonesia yang memiliki keragaman sosial budaya memiliki presentase $(87,27 \%)$, berkomunikasi dengan komunitas profesi sendiri dan profesi lain secara lisan dan tulisan atau bentuk lain memiliki prsentase (88,18\%). Jadi dapat disimpulkan bahwa dari ke empat item di atas, indikator berkomunikasi secara efektif, empatik, dan santun sesama pendidik, tenaga kependidikan, orang dan masyarakat merupakan skor tertinggi dengan presentase $(89,70 \%)$.
Sedangkan untuk skor terendah adalah beradaptasi di tempat bertugas di seluruh wilayah republik indonesia yang memiliki keragaman sosial budaya dengan presentase $(87,27 \%)$.

\section{PEMBAHASAN}

Berdasarkan hasil penelitian yang diperoleh bahwa pembahasan mengenai Persepsi Kepala Sekolah Terhadap Kinerja Guru PJOK Sekolah Menengah Atas Negeri di Kota Bengkulu adalah Sebagai Berikut:

Berdasarkan hasil kuesioner Kepala Sekolah Se-SMA Negeri di Kota Bengkulu yang terdiri dari 4 kategori yaitu Kompetensi Pedagogik Guru PJOK yang ada disekolah tersebut maka didapatkan data dengan mean 4,31 dan persentasi $(86,18 \%)$ termasuk kriteria sangat baik. Dimana guru mampu untuk mengembangkan5 indikator yaitu : (1) Memahami peserta didik lebih mendalam, (2) Merancang pembelajaran termasuk memahami landasan pendidikan untuk kepentingan pembelajaran, (3) Melaksanakan pembelajaran, (4) Merancang dan melaksanakan evaluasi pembelajaran, (5) Mengembangkan potensi peserta didik. Seperti yang di kemukakan (Paturusi, 2012:101), kompetensi pedagogik merupakan kemampuan guru yang berkenaan dengan pemahaman peserta didik dan pengelola pembelajaran yang mendidik dan dialogis. Secara subtantif kompetensi ini mencakup kemampuan pemahaman terhadap peserta didik, perancangan dan pelaksanaan pembelajaran, evaluasi hasil belajar dan pengembangan peserta didik untuk mengaktualisasikan berbagai potensi yang dimilikinya. Kompetensi Kepribadian Guru PJOK yang ada 
disekolah tersebut maka didapatkan data dengan mean 4,37 dan persentasi $(87,45) \%$ termasuk kriteria sangat baik. Dimana guru mampu untuk mengembangkan 5 indikator yaitu : (1) Bertindak sesuai dengan norma agama, hukum, sosial dan kebudayaan nasional Indonesia, (2) Menampilkan diri sebagai pribadi yang jujur, berakhlak mulia, dan teladan bagi peserta didik dan masyarakat, (3) Menampilkan diri sebagai pribadi yang mantap, stabil, dewasa, arif dan berwibawa, (4) Etos kerja, tanggung jawab yang tinggi, rasa bangga menjadi guru dan rasa percaya diri, (5) Menjunjung tinggi kode etik profesi guru. Seperti yang di kemukakan menurut Permadi dan Arifin (2013) mengatakan bahwa kompetensi kepribadian guru memiliki pengaruh yang sangat besar terhadap pertumbuhan dan perkembangan kepribadian peserta didik karena guru merupakan teladan bagi peserta didiknya untuk itu seorang guru harus memiliki kepribadian yang baik. Kompetensi Profesional Guru PJOK yang ada disekolah tersebut maka didapatkan data dengan mean 4,28 dan persentasi $(85,64 \%)$ termasuk kriteria sangat baik. Dimana guru mampu untuk mengembangkan 4 indikator yaitu : (1) Penguasaan materi struktur konsep dan pola pikir keilmuan yang mendukung mata pelajaran yang diampu, (2) Menguasai standar kompetensi dan kompetensi dasar mata pelajaran yang diampu, (3) Mengembangkan keprofesian melalui tindakan reflektif, (4) Memanfaatkan teknologi informasi dan komunikasi untuk mengembangkan diri. Seperti yang di kemukakan menurut Permadi dan Arifin (2013), mengatakan bahwa kompetensi profesional adalah kemampuan guru menguasai materi pembelajaran secara luas dan mendalam yang memungkinkan untuk membimbing peserta didik memenuhi standar kompetensi yang ditetapkan, selain itu guru juga harus lebih dinamis dan kreatif dalam mengembangkan proses pembelajaran agar peserta didik tidak bosan pada saat pembelajaran. Kompetensi Sosial Guru PJOK yang ada disekolah tersebut maka didapatkan data dengan mean 4,42 dan persentasi $(88,36 \%)$ termasuk kriteria yang sangat baik. Dimana guru mampu untuk mengembangkan 5 indikator yaitu : (1) Bersikap inklusif, bertindak obyektif, serta tidak diskriminatif, (2) Berkomunikasi secara efektif, empatik, dan santun dengan sesama pendidik, tenaga kependidikan, orang tua, dan masyarakat, (3) Beradaptasi ditempat bertugas di seluruh wilayah Republik Indonesia yang memiliki keragaman sosial budaya, (4) Berkomunikasi dengan komunitas profesi sendiri dan profesi lain secara lisan dan tulisan atau bentuk lain. Seperti yang di kemukakan (Sukmadinata, 2006:88) "diantara kemampuan sosial dan personal yang paling mendasar yang harus dikuasai guru adalah idealisme, yaitu cita-cita luhur yang ingin di capai dengan pendidikan".

\section{PENUTUP}

\section{SIMPULAN DAN SARAN}

Hasil kuesioner Kepala Sekolah Menengah Atas Negeri Kota Bengkulu yang terdiri dari empat kategori yaitu Kompetensi Pedagogik, Kompetensi Kepribadian, Kompetensi Profesional, Kompetensi Sosial adapun hasil persentase dari empat kategori tersebut adalah Kompetensi Pedagogik sebesar $86,18 \%$ termasuk kategori 
sangat baik, untuk Kompetensi Kepribadian sebesar $87,45 \%$ termasuk kategori sangat baik, adapun Kompetensi Profesional sebesar $85,64 \%$ termasuk kategori sangat baik, dan untuk Kompetensi Sosial sebesar $88,36 \%$ termasuk kategori sangat baik. Hasil ini membuktikan bahwa Persepsi Kepala sekolah Terhadap Kinerja Guru PJOK Sekolah Menengah Atas Negeri di Kota Bengkulu sudah sangat baik.

1. Kepada Guru khususnya Guru PJOK lebih mengedepankan 4 kompetensi guru agar kegiatan mengajar di sekolah berjalan lebih baik lagi dari sebelumya dan sesuai apa yang diinginkan Kepala Sekolah di sekolah tersebut, selanjutnya guru PJOK bisa menjadi contoh dan motivasi untuk para peserta didik di sekolah tersebut.

2. Kepada Kepala Sekolah diharapkan untuk bisa memberikan motivasi, masukan dan sekali-kali mengadakan super visi untuk mengetahui kemampuan guru dalarn melaksanakan pembelajaran serta dukungan dari Kepala Sekolah, agar proses pembelajaran dapat berjalan dengan baik.

3. Kepada peneliti selanjutnya khususnya di bidang Penjas yang akan melakukan penelitian dalam tema yang sama diharapkan agar menggunakan sampel yang lebih besar dengan variabel-variabel yang lain. Sehingga diharapkan hasil penelitian yang di dapat, akan lebih maksimal hasilnya.

\section{DAFTAR PUSTAKA}

Arikunto, Suharsimi. 2006 . Metode Penelitian Kualitatif,
Kuantitatif, dan R\&D. Jakarta : Bumi Aksara.

Desmita. 2006 . Psikologi

Perkembangan. Bandung:

Remaja Rosdakarya.

Gunawan, Imam. 2013. Metode Penelitian Kualitatif Teori dan Praktek. Jakarta : $\quad$ PT Bumi Aksara.

Insanistyo, B. Pujianto, D. 2018 Manajemen Pendidikan Jasmani dan Olahraga.Bengkulu : FKIP Universitas Bengkulu.

Mulyasa, E. 2006 . Menjadi Guru Profesional Menciptakan Pembelajaran Kreatif dan Menyenangkan. Bandung : PT Remaja Rosdakarya.

Sugiyono. 2013 . Metode Penelitian Manajemen. Bandung : Alfabeta.

Supardi. 2013 . Kinerja Guru. Jakarta : PT Raja Grafindo Persada.

Uno, H.B \& Lamatenggo, Nina. 2014. Teori Kinerja dan Pengukurannya. Jakarta : Bumi Aksara.

Wahjosumidjo. 2005 . Kepemimpinan Kepala Sekolah Tinjauan Teoritik dan Permasalahannya. Jakarta : PT Raja Grafindo Persada.

Walgito, Bimo. 2004 . Pengantar Psikologi Umum. Yogyakarta : Andi Offset. 